to massive liability. There was also breadth in the arbitrator pool. Nevertheless, the data suggested that there is room for improvement in the dispute resolution process.

Empirical legal studies can and should inform the evaluation and management of investment treaties and related conflict. More empirical research, done in a scientifically valid and reliable manner, is needed to provide accurate information that stakeholders might usefully consider. Governments might usefully use such information in treaty negotiation, treaty revision and decisions to intervene in cases to which it is not a party. Parties, lawyers, and arbitrators might use the information to use the system more efficiently, provide better advice, make more informed determinations, and better understand the cost and benefits of various dispute resolution strategies. Non-parties also have the ability to make more informed critiques of and interventions in the process.

Overall, should we be willing to utilize it, empirical work can create international law institutions and develop international law theories that are grounded in an empirical reality. This in turn can promote accountability and responsiveness to stakeholders. While the use of such empirical data and their analytical inferences is ultimately a matter of choice and political will, the creation and use of these data has the capacity to promote the legitimacy of an international law process that impacts the daily lives of litigants, governments, and taxpayers alike.

\title{
The Evolving International Standard and Sovereignty
}

\section{By W. Michael Reisman ${ }^{*}$}

In its modern sense, sovereignty is simply the demand of each territorial community, however small and weak, and however governed, to be permitted to govern itself without interference by larger or more powerful states and, at least in 1945, without interference by any agency of the organized international community. ${ }^{1}$ But the ink was scarcely dry on the UN Charter before the notion of a sovereign domain reservé came under assault from more and more international programs. Each has contributed to expanding the content of the omnibus term, "international minimum standard" into an ambitious and comprehensive governance code of legal and administrative requirements.

As in much international law, implementation has proven episodic and opportunistic. In the macro-economic sphere, international financial institutions used "conditionality" to compel changes in the internal arrangements of states, so-called "structural adjustments," before financial benefits would be extended. The European Union has relied on forms of conditionality with respect to compliance with international human rights prescriptions as a condition for extending recognition or allowing membership in the European system.

Of late, international investment law and its instruments and instrumentalities have come to play a more particularized and assertive role in expanding and applying the international standard. Bilateral investment treaties, or BITs (of which there are some 2,500), seek to establish an orderly framework for investment by creating, in the language of a typical United Kingdom BIT, "favorable conditions for greater investment by nationals and companies of one state in the territory of the other state." The term "favorable conditions" has become code for appropriate internal legal, administrative and regulatory arrangements-all conducted through "transparent" procedures designed to ensure that the arrangements are applied as

\footnotetext{
* Myres S. McDougal Professor of International Law, Yale Law School.

${ }^{1}$ United Nations Charter, Art. 2(7).
} 
they are supposed to be applied. "Favorable conditions" require an effective normative framework, comprised of impartial courts, an efficient and legally restrained bureaucracy and the measure of transparency in decision-making which is now recognized as a necessary part of the ensemble of control mechanisms over governments and a component of the international standard of governance.

BITs, in the aggregate, are thus influencing the content of the "international standard," by raising international law's bar for the way states are expected to conduct their internal affairs through the concept of "fair and equitable treatment." Matters have gone from the Neer standard of " an outrage . . bad faith . . . a willful neglect of duty . . . an insufficiency of governmental action," to a lower and more nuanced standard that actually involves a much more searching inquiry into the administrative actions of the respondent government. ${ }^{2}$ Waste Management II, which undertook to summarize and synthesize the case law until that time, spoke of conduct that was "arbitrary, grossly unfair, unjust or idiosyncratic." 3

Of course, international law is replete with largely unenforceable injunctions. What is different here is that most BITs allow qualifying investors themselves, without the espousal, permission, or blessing of their state of nationality, to invoke an international tribunal to review host state action, in terms of whether it has constituted "fair and equitable" treatment. This procedural change has had major substantive effects. Sir Henry Maine observed that "so great is the ascendency of the Law of Actions in the infancy of Courts of Justice, that substantive law has at first the look of being gradually secreted in the interstices of procedure." 4 The observation also applies to this stage of development of international law: the procedural innovation-the ascription of international standing to the investor-has transformed what was heretofore only intermittently applied law into effective law. Considerable diplomatic capital is consumed in each governmental demarche against another; many other urgent issues have claims on that capital. So as long as international standards could only be enforced by states, governments were pressed to ignore or proceed "deliberately" or inconsistently with respect to many of the deprivations its nationals claimed to have suffered.

With the initiative for enforcement transferred entirely to a private party with an economic interest in the outcome, the possibility of an espousing government's disinterest militating against its national's claim does not arise. Thus, there is more and more invocation of thirdparty decision, more demands for enforcement, and more supervision of domestic legal processes.

Along with the right of private initiation of claims, the scope of appraisal has expanded dramatically. Contrast the high thresholds set in Neer and Chattin, which we considered earlier, with some current formulations. In Metalclad, the Tribunal said that "[t]he totality of these circumstances demonstrates a lack of orderly process and timely disposition in relation to an investor of a Party acting in the expectation that it would be treated fairly and justly." In Tecmed, in a paragraph that has been recited by many other Tribunals, the Tribunal said:

\footnotetext{
${ }^{2}$ Neer v. Mexico, para. 4 (U.S.-Mex. Gen. Cl. Comm'n, Oct. 15, 1926).

${ }^{3}$ Waste Management, Inc. v. United Mexican States, ICSID Award of April 30, 2004 at paragraph 98, pages 35-36.

${ }^{4}$ Henry Sumner Maine, Dissertations on Early Law and Custom 389 (1891).

${ }^{5}$ Metalclad Corp. v. Mexico, Award (NAFTA Ch. 11 Arb. Trib. Aug. 30, 2000, paragraph 99 at page 27) (discussed in case report by William S. Dodge, at 95 AJIL 910 (2001)).
} 
The foreign investor expects the host State to act in a consistent manner, free from ambiguity and totally transparently in its relations with the foreign investor, so that it may know beforehand any and all rules and regulations that will govern its investments, as well as the goals of the relevant policies and administrative practices or directives, to be able to plan its investment and comply with such regulations. Any and all State actions conforming to such criteria should relate not only to the guidelines, directives or requirements issued, or the resolutions approved thereunder, but also the goals underlying such regulations. (emphasis added) ${ }^{6}$

Even more far-reaching is the statement in Occidental v. Ecuador, where the Tribunal said: "The relevant question for international law in this discussion is . . rather whether the legal and business framework meets the requirements of stability and predictability under international law." 7

In addition to appraising the adequacy of the total administrative structure of a respondent state, international investment tribunals are increasingly making appraisals of the propriety of specific national administrative actions with respect to a foreign investor in terms of the law of the Respondent as well as by an international standard of comportment. Consider one other paragraph from the Occidental award:

The Tribunal agrees with the [Internal Revenue Service of Ecuador] that Article 69A [of the Tax Code] grants the right to a tax refund to exporters of goods involved in activities such as mining, fishing, lumber, bananas and African palm oil. The Tribunal does not, however, agree that the oil industry is excluded from the application of Article 69A. ... As has been explained above, the Tribunal has concluded that VAT reimbursement was not included in [Occidental's] Contract. It follows that under Ecuadorian tax legislation the Claimant is entitled to such a refund. ${ }^{8}$

Thus, international investment tribunals are tending toward a dédoublement fonctionnel: First, reviewing the adequacy of the entire administrative framework in terms of international law standards. Second, reviewing the administrative action of a respondent state in terms of its propriety and accuracy under its own law.

This expanded review of matters heretofore deemed quintessentially domestic is raising acute problems within states because of two coinciding factors. The first is the transformation in governance modes within states seeking development from the Laissez-Faire model to the Regulatory model. It is appreciated that the accommodation of an efficient economy with the complex political demands of democratic states, the protection of the most vulnerable strata of the population, and the preservation of the environment all require a continuing managerial approach to internal economic activity. Just as the developing state is learning to manage its political economy, the international system is subjecting the efforts of all states to greater and greater external scrutiny. The second new factor is the dramatic empowerment of civil society in the host state and the extent to which it is now capable of pressing visions of national interest which are not necessarily identical to those pursued by the national government.

The expanded role of international investment law has been resisted in many different ways by states themselves-and not only by developing states. One response is the attempt to discard international arbitration as a mode of dispute resolution for foreign investment matters. Another has been an attempt to revive the Calvo Doctrine in new raiment. Its vehicle

\footnotetext{
${ }^{6}$ Tecnicas Medioambientales Tecmed S.A. v. The United Mexican States (ICSID Award of May 29, 2003), paragraph 154 at page 61 .

${ }^{7}$ Occidental Exploration \& Prod. Co. v. Ecuador, para. 191 (UNCITRAL July 1, 2004).

${ }^{8} I d$., at paragraphs 136 and 143.
} 
is not a formal Calvo Clause but, rather, an insistence on the preeminence of choice of law and forum clauses in contracts with foreign investors over international commitments. If the investor accepts such clauses after arms-length negotiation, it is argued, then the matter falls to be decided by local courts according to local law. That argument would certainly be correct in the absence of an investment treaty imposing obligations on a state which had used the treaty as a means for inducing foreign investment. Where there is such a treaty, it is difficult to sustain such an argument.

In these cross-currents, international investment law's role in the growth and maintenance of a robust global economy will depend, in significant measure, on the wisdom and sensitivity of international investment law tribunals, each of which is an ephemeral custodian of the international standard. It will also depend, as does so much of international law, on the practices of the major states of the world. Now that the United States has become the largest capital importer in the world, will it continue to support the important advances achieved over the past half century in the architecture of the international standard or decide to throw its considerable weight toward dismantling it?

\section{International Investment and Administrative Law in Latin America}

$$
\text { By Javier Robalino-Orellana* }
$$

\section{INTRODUCTION}

I will approach this issue from two perspectives: first, Latin American administrative law in the context of international investment law; second, the influence of international investment law on domestic administrative law.

Administrative law in Latin America is a typical area of law in any country ruled by civil law, as most Latin American states are. However, administrative law is no less important than other areas. As opposed to what many may think, it is currently one of the most important and comprehensive areas. Administrative law includes any area of law where an administrative power is present. By exclusion, administrative powers are not judicial or legislative powers. Hence, administrative powers include those related to oil, telecommunications, energy, concessions, environment, etc., whether deriving from federal, state, or provincial authorities. In other words, administrative law governs and regulates most investments in the region. This means that actions by any government body (other than judicial or legislative actions) fall within the sphere of administrative law.

Furthermore, if investments are formalized by means of a contract, the contract will most probably be one of the so-called administrative contracts or contrat administratif. ${ }^{1}$ This means that the contract will be governed by public policy principles of administrative law, and not by principles of private civil law. Therefore, the foreign investor, upon entering into such contract, has accepted to be subject to domestic public law.

Administrative law is comprised in a hierarchical regulatory structure. Generally, it supersedes private law, but is also superseded by constitutional and international law. ${ }^{2}$ Also,

\footnotetext{
* Partner, Perez Bustamante \& Perez, Quito, Ecuador; Professor of Administrative Law, Universidad San Francisco de Quito.

1 See Hector Mairal, Government Contracts Under Argentine Law: A Comparative Law Overview, 26 FordHAM INT'L L.J. 1724 (2002-2003) (the theory of the contract administratif has its origin in France).

${ }^{2}$ See, e.g., Carlos Nahuel Oddone et al., La protección del inversor extranjero y el arbitraje internacional en la Argentina, at <http://www.eumed.net/cursecon/ecolat/ar/2005/nolg-prot.htm>.
} 